\title{
Expectations of patients towards a primary care physician, related to the reason for the current visit, with particular emphasis on patients aged 65+
}

\author{
Oczekiwania badanych pacjentów wobec lekarza podstawowej opieki zdrowotnej, \\ związane z powodem aktualnej wizyty, ze szczególnym uwzględnieniem \\ pacjentów w wieku 65+
}

AGNIESZKA KATARZYNA STRZELECKA', A-G, GRAŻYNA NOWAK-STARZ1, в, D, E, BEATA KARAKIEWICZ2, D-F

${ }^{1}$ Instytut Zdrowia Publicznego Wydziału Nauk o Zdrowiu Uniwersytetu Jana Kochanowskiego w Kielcach ${ }^{2}$ Zakład Zdrowia Publicznego Wydziału Nauk o Zdrowiu Pomorskiego Uniwersytetu Medycznego w Szczecinie

A - Study Design, B - Data Collection, C - Statistical Analysis, D - Data Interpretation, E - Manuscript Preparation, $\mathbf{F}$ - Literature Search, $\mathbf{G}$ - Funds Collection

Summary Background. The patient during the visit seeks explanation of the disease, emotional support and information on tests and further diagnosis.

Objectives. The aim of this study was to investigate the expectations of the patients towards a primary care physician, related to the reason for the current visit, with particular emphasis on patients $65+$.

Material and methods. The study was conducted in selected primary care institutions in Świętokrzyskie region, where a total of 422 patients were surveyed. The study used PRF research tool. The statements contained in the PRF include three factors that relate to expectations connected with the explanation of disease, the search for emotional support and obtaining information on tests. For statistical analysis $U$ Mann-Whitney-Wilcoxon test, Kruskal-Wallis test and the $\chi^{2}$ test were used.

Results. The declared need to explain the disease is varied in age groups at a significance level of $p=0.027$. The need for emotional support is varied in age groups at a significance level of $p=0.001$. People aged 30-44 years have significantly lower declared need for emotional support than those aged $45-64$ years and those aged 65 years and more $(p=0.02)$. The studies have shown that the declared need for information on tests and treatment is varied in age groups at a significance level of $p=0.001$. However, no statistically significant differences were found in the need for information between studied patients over $65+$ and the other age groups.

Conclusions. The study showed that the main reason for visits of patients over 65 to a primary care physician is expectation to receive emotional support.

Key words: patient, primary health care, patient expectations, Patient Request Form.

Streszczenie Wstęp. Pacjent podczas wizyty lekarskiej oczekuje wyjaśnienia choroby, wsparcia emocjonalnego oraz informacji na temat badań i dalszej diagnozy.

Cel pracy. Poznanie oczekiwań badanych pacjentów wobec lekarza podstawowej opieki zdrowotnej, związanych z aktualną wizytą, ze szczególnym uwzględnieniem pacjentów powyżej 65. roku życia.

Materiał i metody. Badania zostały przeprowadzone w wylosowanych placówkach podstawowej opieki zdrowotnej na terenie województwa świętokrzyskiego, w których przebadano łącznie 422 pacjentów. W badaniach zastosowano narzędzie badawcze Lista Oczekiwań Pacjenta - PRF (Patient Request Form). Stwierdzenia zawarte w PRF obejmują trzy czynniki, które dotyczą oczekiwań związanych z wyjaśnieniem choroby, poszukiwaniem wsparcia emocjonalnego oraz uzyskaniem informacji na temat badań i leczenia. Do analizy statystycznej, oprócz statystyki opisowej, wykorzystano test U Manna-Whitneya-Wilcoxona, test Kruskala-Wallisa i test zgodności $\chi^{2}$.

Wyniki. Deklarowana potrzeba wyjaśnienia choroby jest zróżnicowana w grupach wiekowych na poziomie istotności $p=$ 0,027 . Potrzeba wsparcia emocjonalnego jest zróżnicowana $w$ grupach wiekowych na poziomie istotności $p=0,001$. Osoby w wieku 30-44 lat mają istotnie mniejszą deklarowaną potrzebę wsparcia emocjonalnego niż osoby w wieku 45-64 lat oraz osoby w wieku 65 lat i więcej $(p=0,02)$. Przeprowadzone badania wykazały, że potrzeba informacji na temat badań i leczenia jest zróżnicowana w grupach wiekowych na poziomie istotności $p=0,001$. Nie znaleziono jednak istotnych różnic statystycznych w potrzebie informacji między badanymi pacjentami w wieku powyżej 65 lat a innymi grupami wiekowymi.

Wnioski. Przeprowadzone badania wykazały, że głównymi przyczynami zgłaszania się pacjentów powyżej 65. roku życia do lekarza podstawowej opieki zdrowotnej jest oczekiwanie otrzymania wsparcia emocjonalnego. Pozostali pacjenci będący w różnych grupach wiekowych oczekują przede wszystkim wyjaśnienia choroby i informacji na temat dalszego leczenia. Słowa kluczowe: podstawowa opieka zdrowotna, pacjent, oczekiwania pacjenta, Lista Oczekiwań Pacjenta.

Fam Med Prim Care Rev 2015; 17(3): 215-218

\section{Background}

Meeting the expectations of a patient towards the health care system influences the sense of satisfaction of both, the patient and the doctor. After the system changes in CentralEastern Europe in the early nineties of XX century, a key role in primary care was taken over by a family doctor $[1,2]$. In 
1993, a specialization in family medicine was introduced as a "part of an overall strategy to enhance the role and improve the quality of primary health care" [3]. Primary health care is supposed to be the "foundation of the whole health care system, based on the activity of family doctors and nurses. The members of these professional groups are to be guides (and also coordinators) on the health care system, responsible for cooperation with both specialized healthcare centers (open and closed), as well as social welfare" [4]. A patient during the visit shares their problems, not only health but also psychological and emotional ones, with a family doctor. The doctor should treat the patient subjectively, remaining open to his/her needs. Because of the respect for the will of the patient, the physician must submit a patient's state of health, diagnosis and possible alternatives of treatment. In the doctor-patient interaction, mutual respect for subjects and lack of superiority of one of them is also important $[5,6]$.

\section{Objectives}

The aim of this study was to investigate the expectations of the patients towards a primary care physician, related to the reason for the current visit, with particular emphasis on patients aged over 65 .

\section{Material and methods}

The study was conducted in randomly selected primary care institutions in Świętokrzyskie region, where the total of 422 patients were surveyed including 163 (38.63\%) men and 259 (61.37\% women). Overall, among the surveyed people the prevailing age range was $45-64$ years $32.23 \%$ (136), respectively $30-44$ years $24.64 \%$ (104), 20-29 years $24.17 \%$ (102), 65 years and older $13.51 \%$ (57) and 18-19 $5.45 \%$ (23). Managers of the randomly selected institutions gave their consent to conduct anonymous surveys. In total, for 422 respondents, $51.90 \%$ (219) of patients indicated village as a place of residence, $19.19 \%$ (81) town of 20-100 thousand, $18.01 \%$ (76) city of $101-500$ thousand and $10.90 \%$ (46) the city of up to 20 thousand. The largest group among the studied patients were people with secondary education 35.78\% (151) and next with higher MA 26.78\% (113), vocational $18.01 \%(76)$, primary $12.09 \%$ (51) and higher undergraduate $7.35 \%$ (31). The vast majority of all respondents were people in relationships $62.32 \%$ (263), single people $28.20 \%$ (119) and the category of widow/widower was indicated by $9.48 \%$ (40) of the respondents.

The study used the research tool called Patient Request Form (PRF). PRF is a modification of a questionnaire developed by Good et al. (1983) intended for primary care patients. partment of Psychology, The University of Liverpool, and the adaptation of this test was dealt with by Zygfryd Juczyński, Psychological Test Laboratory of Polish Psychological Association [7]. Polish version of the Patient Request Form (PRF) consists of 18 statements regarding various reasons for the current visit to a general practitioner. The test indicates to what extent the content of the statement expresses reasons to seek medical advice. The statements contained in PRF are a part of the three factors that relate to expectations connected with the explanation of the disease, the search for emotional support and obtaining information on tests and treatment.

To collect and analyze test results, Microsoft Excel and Statistica 10 were used. For statistical analysis, in addition to descriptive statistics, U Mann-Whitney-Wilcoxon test, Kruskal-Wallis test and the $\chi^{2}$ test were used. Significance was assumed at $p<0.05$.

\section{Results}

The analysis of the studied parameter, which is the assessment of one's health status, showed that $41.00 \%(173)$ of the respondents assessed their health as good, 24.64\% (104) as satisfactory, $18.25 \%$ (77) as very good, $13.74 \%$, as weak and $2.37 \%$ (10) indicated the category of perfect. When analysing the assessment of health status by the patients, two variables were created: age $<65$ years, and the age $65+($ Tab. 1$)$.

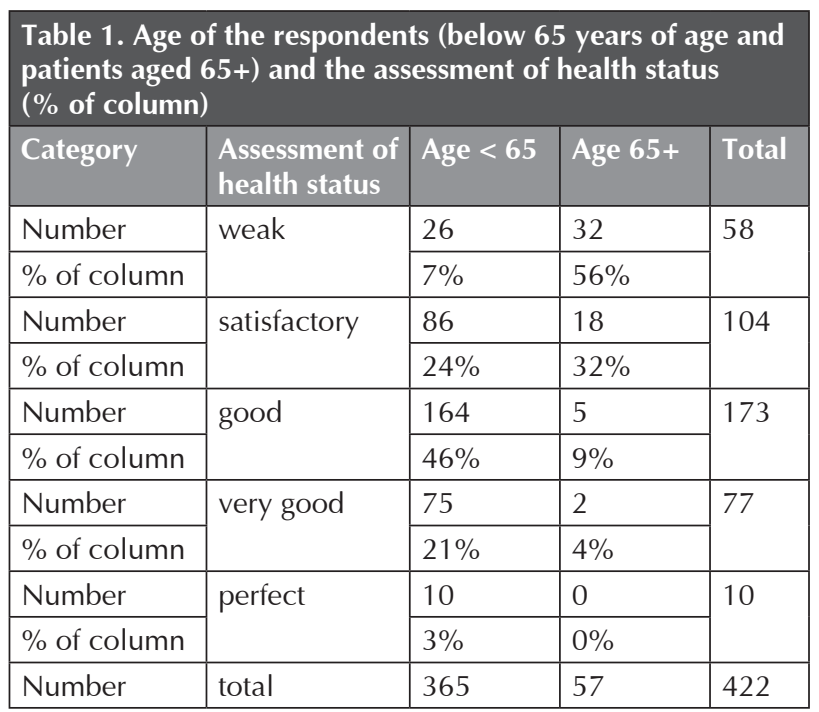

The studied patients over 65 years old in more than a half of cases assessed their health as poor. Respondents under 65 stated that their health is poor 8 times less. There

\begin{tabular}{|c|c|c|c|c|c|c|c|}
\hline \multirow[t]{2}{*}{ Category } & \multirow{2}{*}{$\begin{array}{l}\text { Assessment of material } \\
\text { conditions }\end{array}$} & \multicolumn{5}{|c|}{ Age of the respondents } & \multirow[t]{2}{*}{ Total } \\
\hline & & $18-19$ & $20-29$ & $30-44$ & $45-64$ & $65+$ & \\
\hline Number & \multirow[t]{2}{*}{ bad } & 0 & 4 & 5 & 6 & 12 & \multirow[t]{2}{*}{27} \\
\hline$\%$ of column & & $0 \%$ & $4 \%$ & $5 \%$ & $4 \%$ & $21 \%$ & \\
\hline Number & \multirow[t]{2}{*}{ average } & 4 & 38 & 32 & 62 & 30 & \multirow[t]{2}{*}{166} \\
\hline$\%$ of column & & $17 \%$ & $37 \%$ & $31 \%$ & $46 \%$ & $53 \%$ & \\
\hline Number & \multirow[t]{2}{*}{ good } & 15 & 45 & 50 & 55 & 13 & \multirow[t]{2}{*}{178} \\
\hline$\%$ of column & & $65 \%$ & $44 \%$ & $48 \%$ & $40 \%$ & $23 \%$ & \\
\hline Number & \multirow[t]{2}{*}{ very good } & 4 & 15 & 17 & 13 & 2 & \multirow[t]{2}{*}{51} \\
\hline$\%$ of column & & $17 \%$ & $15 \%$ & $16 \%$ & $10 \%$ & $4 \%$ & \\
\hline Number & total & 23 & 102 & 104 & 136 & 57 & 422 \\
\hline
\end{tabular}


is a significant relationship between the age structure and the assessment of their health $\left(\chi^{2}\right.$ test; $\left.p<0.0001 ; \mathrm{Fi}=0.52\right)$.

The studies have shown a significant correlation between age structure and the assessment of their own material conditions $\left(\chi^{2} ; p<0.0001 ; \mathrm{Fi}=0.34\right)$ of the patients. People aged over 65 in most cases assessed their material conditions as average (Tab. 2).

Age groups under 65 most often identified their material situation as good. The study group $65+$ is the only age group in which poor material conditions were not the rarest choice.

The declared need to clarify the disease is varied in age groups at a significance level of $p=0.027$ (Tab. 3).

\begin{tabular}{|c|c|c|c|c|}
\hline \multirow[t]{2}{*}{$\begin{array}{l}\text { Variable: } \\
\text { Explanation }\end{array}$} & \multicolumn{4}{|c|}{$\begin{array}{l}\text { ANOVA Kruskal-Wallis rank; Explanation (PRF } \\
\text { base) independent variable (grouping): Age of } \\
\text { respondents Kruskal-Wallis test: } H(4, n=422) \\
=10.92223 ; p=0.0275\end{array}$} \\
\hline & code & $n$ valid & rank sum & average rank \\
\hline 18-19 & 1 & 23 & 3949.50 & 171.7174 \\
\hline $20-29$ & 2 & 102 & 20008.50 & 196.1618 \\
\hline $30-34$ & 3 & 104 & 20773.50 & 199.7452 \\
\hline $45-64$ & 4 & 136 & 30954.00 & 227.6029 \\
\hline $65+$ & 5 & 57 & 13567.50 & 238.0263 \\
\hline
\end{tabular}

After correction for multiple comparisons, no pairs of groups were found that are significantly different in terms of the expected clarification of disease of the study population. Therefore, it can be concluded that age does not affect the expected clarification of the disease during the visit. There were no significant statistical differences of the required clarification of the disease between medians of the study group $65+$ and other age groups $(p>0.05)$.

The declared need for emotional support is varied in age groups at a significance level of $p=0.0011$. After correction for multiple comparisons, at least one pair of groups that differs significantly in terms of the expected support was found (Tab. 4).

Table 4. Age of the patients and the expectations related to the search for emotional support (Kruskal-Wallis test)

\begin{tabular}{|c|c|c|c|c|}
\hline \multirow[t]{2}{*}{$\begin{array}{l}\text { Variable: } \\
\text { Support }\end{array}$} & \multicolumn{4}{|c|}{$\begin{array}{l}\text { ANOVA Kruskal-Wallis rank; Explanation } \\
\text { (PRF base) independent variable (grouping): } \\
\text { Age of respondents Kruskal-Wallis test: } \\
\text { H }(4, n=422)=18,35831 ; p=0.0011\end{array}$} \\
\hline & code & $n$ valid & rank sum & average rank \\
\hline $18-19$ & 1 & 23 & 4443.50 & 193.1957 \\
\hline $20-29$ & 2 & 102 & 20074.50 & 196.8088 \\
\hline $30-34$ & 3 & 104 & 18888.50 & 181.6202 \\
\hline $45-64$ & 4 & 136 & 31907.00 & 234.6103 \\
\hline $65+$ & 5 & 57 & 13939.50 & 244.5526 \\
\hline
\end{tabular}

Therefore, it can be concluded that age has an impact on the expected emotional support $(p<0.05)$ during a visit to a primary care physician. People aged 30-44 have significantly lower declared need for emotional support than those aged $45-64(p<0.01)$ and those aged 65 and older $(p=0.02)$. The median of value of points obtained in people over 65 years of age is 3.33 times bigger than among persons aged 30-44.

The studies have shown that the declared need for information on tests and treatment is varied in age groups at a significance level of $p=0.0011$. After correction for mul- tiple comparisons, at least one pair of groups which is significantly different in terms of the expected information was found (Tab. 5).

\begin{tabular}{|c|c|c|c|c|}
\hline \multirow[t]{2}{*}{$\begin{array}{l}\text { Variable: } \\
\text { Information }\end{array}$} & \multicolumn{4}{|c|}{$\begin{array}{l}\text { ANOVA Kruskal-Wallis rank; Explanation } \\
\text { (PRF base) independent variable (grouping): } \\
\text { Age of respondents Kruskal-Wallis test: } \\
\text { H }(4, n=422)=18,19256 ; p=0.0011\end{array}$} \\
\hline & code & $n$ valid & rank sum & average rank \\
\hline 18-19 & 1 & 23 & 4255.50 & 185.0217 \\
\hline $20-29$ & 2 & 102 & 18915.50 & 185.4461 \\
\hline $30-34$ & 3 & 104 & 20130.50 & 193.5625 \\
\hline $45-64$ & 4 & 136 & 32953.00 & 242.3015 \\
\hline $65+$ & 5 & 57 & 12998.50 & 228.0439 \\
\hline
\end{tabular}

The studies have shown that the age of patients has an impact on their expectations related to obtaining information on tests and treatment $(p<0.05)$ during a visit to a primary care physician. People in the age group 45-64 have a significantly higher declared need to obtain the information than those aged 20-29 $(p<0.01)$ and those aged 30-44 $(p=0.02)$. But no statistically significant differences were found in the need for information between studied patients over 65 and other age groups.

\section{Discussion}

The group of subjects under 65 at the time of a visit expect from a primary care physician, first of all, to explain the disease and to obtain information on tests and treatment, but emotional support is the least often indicated need of respondents in this age group. Patients over 65 primarily seek emotional support from a doctor. In the studies of Marcinowicz et al., patient expectations were primarily related to obtain information on treatment. However, these studies show that patient-doctor relationship and expressive effectiveness also seem important [8]. The author stresses that emotional support was one of the four main factors shaping the expectations of Lithuanian primary care patients. The study conducted by Kemicer-Chmielewska et al. [9], showed that elderly patients in primary care physicians primarily seek emotional support and mental health. Emotional support received by patients, particularly in the elderly, is extremely important. In the light of the research it seems to be important to provide care for the elderly who need support not only from the physician or medical personnel, but also from the family. The study conducted by Grywalska et al. [10] showed that patients not only expect professional advice in the area of medical recommendations and necessary tests, but it is also important for them to receive spiritual support and assistance in solving personal, family and social problems. Patients feel lonely and socially excluded and at the same time appreciate good family relations [11]. Their lack, a sense of isolation, may contribute to the fact that these people seek help and emotional support from their family doctor.

\section{Conclusions}

The study showed that the main reason for visits of patients over 65 to a primary care physician is the expectation to receive emotional support. Other patients who are in different age groups expect primarily explanation of the disease and information on further treatment. 


\section{References}

1. Seifert B, Svab I, Madis T, et al. Perspectives of family medicine in Central and Eastern Europe. Fam Pract 2008; 25(2): 113-118.

2. Oleszczyk M, Svab I, Seifert B, et al. Family medicine in post-communist Europe needs a boost. Exploring the position of family medicine in healthcare systems of Central and Eastern Europe and Russia. BMC Fam Pract 2012; 13(1): 15-19.

3. Zarys Systemu Ochrony Zdrowia. Polska 2012. World Health Organization 2011. Dostępny na URL:http://akademia.nfz.gov. pl/wp-content/uploads/2013/08/HiT_Polska_2012_z_okladka_automatyczny_spis_tresci.pdf.

4. Ustawa z dnia 27 sierpnia 2004 r. o świadczeniach opieki zdrowotnej finansowanych ze środków publicznych (Dz.U. z 2004 r. nr 210 poz. 2135 z późn. zm.). Dostępny na URL: http://isap.sejm.gov.pl/DetailsServlet?id=WDU20042102135.

5. Bukowska-Piestrzyńska A. Marketing usług zdrowotnych. Od budowania wizerunku placówki do zadowolenia klientów. Warszawa: Wydawnictwo Fachowe CeDeWu.pl; 2012.

6. Krot K. Jakość usług medycznych. Warszawa: Wydawnictwo ABC; 2008.

7. Juczyński Z. Narzędzia pomiaru w promocji i psychologii zdrowia. Warszawa: Pracownia Testów Psychologicznych; 2003.

8. Marcinowicz L, Grębowski R, Fiedorczuk I, i wsp. Oczekiwania pacjentów związane z wizytą u lekarza rodzinnego: analiza treści i próba typologii. Fam Med Prim Care Rev 2010; 12(1): 30-35.

9. Kemicer-Chmielewska E, Rotter I, Pierzak-Sominka J, et al. Geriatrics patients' reasons to visit GPs. J Publ Health 2014; 3: 30-35.

10. Grywalska E, Derkacz M, Chmiel-Perzyńska I, et al. What does allow the physician to win patients' trust? Fam Med Prim Care Rev 2010; 12(3): 662-666.

11. Wróblewska I, Sobik-Niemczynowska B, Błaszczuk J, i wsp. Opinia pacjentów na temat trudności wieku podeszłego oraz roli opieki pielęgniarskiej w kształtowaniu zachowań proaktywnych u osób w wieku podeszłym. Fam Med Prim Care Rev 2014; 16(4): 356-359.

Address for correspondence:

Dr n. o zdr. Agnieszka Katarzyna Strzelecka

Instytut Zdrowia Publicznego

Wydział Nauk o Zdrowiu

Uniwersytet Jana Kochanowskiego w Kielcach

Al. IX Wieków Kielc 19

25-317 Kielce

Tel.: +48 502 733-955

E-mail: agnieszka.strzelecka@ujk.edu.pl

Received: 15.05.2015

Revised: 21.06.2015

Accepted: 22.06.2015 